\title{
SEARCHING FOR HUMAN CAPITAL DETERMINANTS OF FOREIGN DIRECT INVESTMENT INFLOWS IN THE EU NEW MEMBER STATES
}

\author{
Ioan Talpos ${ }^{1}$ \\ Cosmin Enache $e^{2}$
}

\begin{abstract}
The specific levels and patterns of foreign direct investment in the Central and Eastern European countries could not be fully explained taking into account only the traditional economic determinants, as shown in the empirical studies undertaken so far. Hence, we search for some foreign direct investment determinants related with human capital, using panel data techniques, and show that some of the human capital measures are positively correlated with foreign direct investment inflows in Central and Eastern Europe.
\end{abstract}

Key words: foreign direct investment, human capital

JEL codes: F21, J24, C23

\section{Introduction}

The foreign direct investment (FDI) inflows into the Central and Eastern European economies have been a vital factor in the first stage of the privatization process during the transition period. As the privatization and restructuring process came to an end, the main reasons to pursue FDI in this region are to boost productivity, encourage employment, stimulate innovation and technology transfer, and to enhance sustained economic growth (see Mueller and Goic (2002)).

According to a survey by Ernst \& Young (2008), Central and Eastern Europe is regarded by international executives as the third most attractive foreign investment locale after Western Europe and China and is the second most favoured place for investment in the manufacturing industries.

Analyzing the specific patterns of FDI inflows, a very recent study undertaken by Price Waterhouse Coopers (2010) found that FDI as a share of GDP was higher in Central and Eastern European countries with higher relative per capita incomes, lower relative labour costs in manufacturing, lower investor riskiness as measured by credit risk premia on investment and achieved or probable EU membership. But, the study also points out at country-level differences which did not change over time and could not be explained by the variables included in the tested model. So along traditional economic determinants of FDI there must by also others, of noneconomical nature.

Having in mind this idea, we consider that a possible specific determinant of FDI inflows in Central and Eastern Europe could by human capital in the host country.

In order to empirically investigate this hypothesis, we selected as our sample the ten new member states of European Union. All these countries share common characteristics such as: all of them are developing countries and all of them experienced an economic transition to market economy, and as EU members are all inter-connected into a unique framework and also have interfunctional mechanisms.

So, using specific panel data methods we tested the statistical significance as determinant of FDI inflows for several measures of human capital, like the ones related to health (life expectancy

\footnotetext{
1 West University of Timisoara, Faculty of Economics and Business Administration, Pestalozzi 16, Timisoara, ioan.talpos@feaa.uvt.ro

${ }^{2}$ West University of Timisoara, Faculty of Economics and Business Administration, Pestalozzi 16, Timisoara, cosmin.enache@feaa.uvt.ro
} 
at birth, breakdown by sexes, or fertility rate) and the ones related to education (rate of enrolment in secondary education, rate of enrolment in tertiary education, average number of foreign languages learned per pupil, literacy rate).

As expected, some of these human capital measures are positively related to FDI inflows at an acceptable statistical significance level.

\section{Literature review}

The traditional view on FDI determinants take into account the exchange rates, taxes, institutions or trade protection.

We have to mention that while theoretical papers are generous in solid and consistent models, the empirical work is still inconclusive. For example, two of the most influential papers in this field, Campa (1993) and Goldberg and Kolstad (1995) have apparently contradictive hypothesis which both confirm using US datasets.

The effect of exchange rates on FDI has been examined both with respect to changes in the bilateral level of the exchange rate between countries and in the volatility of exchange rates. All of these models are firm level models of FDI decisions. First, Froot and Stein (1991) concluded that appreciation of host country currency may actually increase foreign investment. Other studies have generally found consistent evidence that short-run movements in exchange rates lead to increased inward FDI, including Grubert and Mutti (1991), Swenson (1994), and Kogut and Chang (1996).

Another important determinants of FDI highlighted in the literature are taxes. Most of the studies, starting with seminal paper of Hartman (1984), are dealing with the impact of corporate income tax from host countries on FDI inflows. While the main strand of the literature in this field focused on corporate income taxes, Desai et al. (2004) pointed to the impact of the indirect business taxes on FDI flows. Bilateral tax treaties pointed at FDI were shown to have a little impact on FDI flows in recent papers like Hallward-Dreimeier (2003) and Blonigen and Davies (2004).

Various studies pointed out the importance of institutions and their quality for FDI decisions of multinational firms. For example, Wei (2000) showed that a variety of corruption indices are strongly and negatively correlated with FDI.

The link between foreign direct investment and trade protection is very obvious: greater the trade protection in a country, greater will be the costs of a firm which exports in that country. So this is a good reason to make a FDI in that country. Despite this simple rationale, the empirical studies provide mixed results (see for instance Blonigen (1997)).

We also found in the literature some studies that tried to find some non-economic determinants of foreign direct investment. A consistent modelling of foreign direct investment flows needs to take into account not only the traditional determinants considered in the literature, but also variables linked to the institutional environment in which such investment is undertaken. Altomonte (2000) showed that the design of an efficient, transparent and enforceable legal and institutional framework is shown to be a crucial determinant of foreign direct investment by modifying investors' expectations. Using a relational approach, Bandelj (2002) showed that political, migration, trade and cultural relations between investor and host countries have strong positive effects on FDI flows.

Regarding Central and Eastern European Countries, using a panel dataset of bilateral flows of foreign direct investment, Bevan and Estrin (2004) showed that in choosing a location in Central and Eastern European for an international investment a set of economic factors such as unit labour costs, gravity factors, market size, and proximity are crucial. Carstensen and Toubal (2004) showed that market potential, low relative unit labour costs, a skilled workforce and relative endowments, the level and method of privatization and the country risk have significant and plausible effects on FDI inflows. Analysing the international investment decisions of the French multinational firms in Central and Eastern Europe , Disdier and Mayer (2004) found that institutional quality is the main determinant of the location decisions. Janicki and Wunnava (2004) 
Human capital importance for FDI decisions is highlighted in papers such as Noorbakhsh Paloni and Youssef (2001), which shoved that human capital is one of the most important determinants of FDI inflows for developing countries.

\section{Research methodology}

The starting idea of our research is that along economic determinants of foreign direct investment another set of factors could play a significant role in attracting foreign direct investment inflows. The theoretical and empirical studies realized so far point out that social capital is a factor which is taken into account in multinational firms international investment decisions.

When we are referring to social capital existing in an economy, we have in mind its broader definition, including into discussion human capital features, cultural values, political rights and freedoms, religion beliefs and economic freedom characteristics.

We consider that human capital could be an important factor in attracting foreign direct investment inflows because multinational corporations which undertake such investment are looking for certain workforce skills levels and endowments.

Cultural values could also play a role in international investment decisions, because is more likely that firm to search for environments with similar cultural features as origin country when choosing a location for a foreign direct investment.

Political status in host country could also be a determinant of foreign direct investment, investor including in their decision function variables like the extension of political rights and freedoms, the stability of the political regime, and the existence of some bilateral political treaties between investor and host countries.

Even if it is less documented in the literature, religion could also play a role in international investment decisions undertaken by firms. It is more likely for a multinational corporation to choose as a location for its abroad investment a host country with the same dominant religion belief as in home country.

Economic freedom in host countries is likely to influence foreign direct investment inflows through the degree of markets liberalization, the level of trade restrictions the degree of freedom to operate on the market and so on.

From the diversity of social capital components which seem to have an impact on foreign direct investment inflows into a country we choose to restrict our empirical research only to human capital related factors. Of course, local human capital is required to absorb foreign direct investment and to achieve a successful technology transfer.

In order to test the hypothesis that human capital in the host economy plays a significant role in attracting foreign direct investment inflows, we choose a sample that consists in the ten European Union New Member States (Bulgaria - BG, Czech Republic - CE, Estonia - ES, Latvia LE, Lithuania - LI, Hungary - UN, Poland - PO, Romania - RO, Slovenia - SN and Slovakia $\mathrm{SC})$, which fit very well together because all of them share common characteristics and historical background.

First of all, in order to highlight the long term induced effects of these human capital FDI determinants, the original data were "cleaned" by uni-periodic shocks, taking into account only their trend. The estimation methodology for the trend is based on weighted moving average (MMP), because such approach offers the possibility to take into account the possible structural breaks in the data sets and also reveals the long term trend:

$$
\operatorname{MMP}\left(X_{t}\right)=\sum_{i=1}^{t} \frac{i}{\sum_{j=1}^{t} j} X_{i}
$$


Regarding the econometric techniques used, we processed the data in a "panel" system, combining time series and data corresponding to different countries. We propose the following simple "pool data" regressive model:

$$
Y_{i t}=\alpha+\beta_{i t} x X_{i t}+\varepsilon_{i t}
$$

where:

- $\mathrm{Y}_{\mathrm{it}}$ is the dependent variable;

$-\alpha$ is the free term coefficient;

- $\beta_{i}$ are the independent variables coefficients;

- $\mathrm{X}_{\mathrm{it}}$ are the independent variables;

- $\varepsilon_{\text {it }}$ is a stochastic variable;

- $i$ is the number of "sections" used to run the regression;

$-t$ is time period.

As a dependent variable we used foreign direct investment inflows as a percentage of GDP, and as independent variables we used several measures of human capital like: life expectancy at birth, differentiated by sexes, fertility rate, persons with lower secondary education attainment (as $\%$ of total population aged 15 to 64), persons with upper secondary education attainment (as \% of total population aged 15 to 64), persons with tertiary education attainment (as \% of total population aged 15 to 64), foreign languages learned per pupil and mathematics, science and technology enrolments and graduates (as \% of all graduates).

We choose only these independent variables because our intention is not to build a comprehensive model of foreign direct investment, but only to highlight some possible determinants which express the quality features of the workforce. In a future research, using the insights depicted from this paper, we intend to extend our work in order to build a foreign direct investment model for developing countries.

We used data for all these countries from Eurostat, the official European Union statistical database, for a period of ten years, ranging from 1999 to 2008.

The obtained results for the pool data regressions are presented in detail in the Annexes. The synthesized form of these results is reported in the following table:

Table no. 1

Estimation results

\begin{tabular}{|c|c|c|c|c|}
\hline Independent Variable & $\begin{array}{c}\text { Estimated } \\
\text { Coefficient }\end{array}$ & $\begin{array}{c}\text { Standard } \\
\text { Error }\end{array}$ & t-Statistics & Probability \\
\hline $\begin{array}{c}\text { Life expectancy at birth - } \\
\text { Females }\end{array}$ & -0.280188 & 0.162737 & -1.721730 & 0.0897 \\
\hline $\begin{array}{c}\text { Life expectancy at birth - } \\
\text { Males }\end{array}$ & 0.157414 & 0.101776 & 1.546678 & 0.1266 \\
\hline Fertility rate & 22.47266 & 3.311426 & 6.786401 & 0.0000 \\
\hline $\begin{array}{c}\text { Persons with lower } \\
\text { secondary education } \\
\text { attainment (as \% of total } \\
\text { population aged 15 to 64) }\end{array}$ & -0.108641 & 0.036271 & -2.995240 & 0.0036 \\
\hline
\end{tabular}




\begin{tabular}{|c|c|c|c|c|}
\hline Independent Variable & $\begin{array}{c}\text { Estimated } \\
\text { Coefficient }\end{array}$ & $\begin{array}{c}\text { Standard } \\
\text { Error }\end{array}$ & t-Statistics & Probability \\
\hline $\begin{array}{c}\text { Persons with upper } \\
\text { secondary education } \\
\text { attainment (as \% of total } \\
\text { population aged 15 to 64) }\end{array}$ & 0.048506 & 0.039702 & 1.221744 & 0.2251 \\
\hline $\begin{array}{c}\text { Persons with tertiary } \\
\text { education attainment (as } \\
\% \text { of total population aged } \\
15 \text { to 64) }\end{array}$ & 0.094938 & 0.045381 & 2.092036 & 0.0393 \\
\hline $\begin{array}{c}\text { Foreign languages learned } \\
\text { per pupil }\end{array}$ & -0.259073 & 0.543147 & -0.476985 & 0.6349 \\
\hline $\begin{array}{c}\text { Mathematics, science and } \\
\text { technology enrolments } \\
\text { and graduates (as \% of all } \\
\text { graduates) }\end{array}$ & 0.132560 & 0.079001 & 1.677967 & 0.0966 \\
\hline
\end{tabular}

Source: Authors calculations using E-Views.

As it could easily see, at a 5\% significance level, only three out of eight independent variables have an adequate statistical relevance.

The fertility rate is positively correlated with foreign direct investment inflows: higher the fertility rate is, higher seems to be the foreign direct investment inflows, showing that one of the variables of the international investment decision function is the (potential) availability of the manpower.

At odds with the theoretical predictions, the percentage of persons with lower secondary education attainment is negatively correlated with the foreign direct investment inflows. This is a specific feature for Central and Eastern European countries, which individualizes these countries in the larger group of the developing countries.

Another specific feature which differentiates the Central and Eastern European countries from the rest of the developing countries is that foreign direct investment flows are positively correlated with the percentage of persons with tertiary education attainment. This situation could be explained if we remind that at the beginning of the transition period, comparative with other developing countries, the Central and Eastern European countries have both higher levels and higher quality of human capital. It seems that international investors took into account this situation and favored these countries for their foreign direct investment, having all the human capital prerequisites for a quicker technological transfer.

If one accepts a $10 \%$ level of statistical significance, the importance of the quality of the human capital for smooth technological transfer between investor and host countries is proved by the positive correlation between the percentage of mathematics, science and technology enrolments and graduates and foreign direct investment inflows.

Other explanatory variables used in estimations seem not to be related with foreign direct investment inflows: foreign languages learned per pupil, the percentage of persons with upper secondary education attainment and life expectancy at birth.

\section{Conclusions}

Foreign direct investment inflows in Central and Eastern Europe have specific patterns and human capital determinants, different from the ones specific to the rest of the developing countries. Our estimations showed that for these countries the quality of the human capital matters in attracting foreign direct investment inflows. It seems that foreign investors in these countries are 
seeking for quick and smooth technological transfer and, hence, value the most the level and the quality of the human capital.

This could be an indicator for public authorities from Central and Eastern Europe countries which are competing for attracting more foreign direct investment. In order to be a more attractive location for international investment it is necessary to invest in education, especially at tertiary level and in the math, science and technical fields.

Of course, our approach is a limited one, because we did not built and tested a comprehensive model of foreign direct investment, and only looked as several possible human capital determinants of the foreign direct investment inflows.

As directions for further research, we intend to broad our approach by taking into account in future research as possible determinants of foreign direct investment inflows: the influence of cultural specific characteristics (quantified by Hoefstede's cultural dimensions or different measures of culture extracted from World Value Surveys), the impact of political status (political freedom, the degree of democracy, the stability of the political regime, the existence of some bilateral treaties between investor and host countries), the possible effects of religion (the investor country could or could not share the same dominant religion with the host country), or the economic freedom, especially the degree of liberalization of the internal markets in the host country. Also, it could be useful a breakdown of foreign direct investment inflows determinants by investor country or by economic sector.

\section{References}

1. Altomonte, C., 2000. Economic determinants and institutional frameworks: FDI in economies in transition, in UNCTAD, 2000, Transnational corporations, vol. 9, no. 2, 75107.

2. Bandelj, N., 2002. Embedded Economies: Social Relations as Determinants of Foreign Direct Investment in Central and Eastern Europe, Social Forces, Vol. 81, No. 2. (Dec., 2002), pp. 411-444.

3. Bevan, A., Estrin, S., 2004. The determinants of foreign direct investment into European transition economies, Journal of Comparative Economics, 32 (2004), 775-787.

4. Blonigen, B. A., 1997. Firm-Specific Assets and the Link Between Exchange Rates and Foreign Direct Investment, American Economic Review, 87, (3), 447-65.

5. Blonigen, B. A., Davies, R. B., 2004. The Effects of Bilateral Tax Treaties on U.S. FDI Activity, International Tax and Public Finance, Vol. 11(September 2004), 601-22.

6. Campa, J., 1993. Entry by Foreign Firms in the United States under Exchange Rate Uncertainty, The Review of Economics and Statistics, 75, 4, 614-622.

7. Carstensen, K., Toubal, F., 2004. Foreign direct investment in Central and Eastern European countries: a dynamic panel analysis, Journal of Comparative Economics, 32, 2004, 3-22.

8. Desai, M. A., Foley, C. F., Hines Jr., J. R., 2004. Foreign Direct Investment in a World of Multiple Taxes, Journal of Public Economics, 88, no. 12, (December 2004), 2727-2744.

9. Disdier, A.-C., Meyer, T., 2004. How different is Eastern Europe? Structure and determinants of location choices by French firms in Eastern and Western Europe, Journal of Comparative Economics, 32, 2004, 280-296.

10. Froot, K. A., Stein, J. C., 1991. Exchange Rates and Foreign Direct Investment. An Imperfect Capital Markets Approach, Quarterly Journal of Economics, 106, (4), 1191-1217.

11. Goldberg, L. S., Kolstad, C. D., 1995. Foreign Direct Investment, Exchange Rate Variability and Demand Uncertainty, International Economic Review, 36,4, 855-873.

12. Grubert, H., Mutti J., 1991. Taxes, Tariffs and Transfer Pricing in Multinational Corporate Decision Making, Review of Economics and Statistics, 73, (2), 285-293. 
13. Hartman, D. G., Tax Policy and Foreign Direct Investment in the US, National Tax Journal, 37, 4, 475-487.

14. Janicki, H. P.,Wunnava, P. V., 2004. Determinants of foreign direct investment: empirical evidence from EU accession candidates, Applied Economics, 36, 505-509.

15. Kogut, B., Chang, S. J., 1996. Platform Investments and Volatile Exchange Rates: Direct Investment in the U.S. by Japanese Electronic Companies, Review of Economics and Statistics, 78, (2), 221-31.

16. Mueller, S. L., Goic, S., 2002. Entrepreneurial Potential in Transition Economies: A view from Tomorrow's Leaders, Journal of Developmental Entrepreneurship, Volume 7, Number 4, December 2002.

17. Noorbakhsh, F., Paloni, A., Youssef, A., 2001. Human Capital and FDI Inflows to Developing Countries: New Empirical Evidence, World Development, 29, 9, 1593-1610.

18. Price Waterhouse Coopers, 2010. Foreign Direct Investment in Central and Eastern Europe. A case of boom and bust?, Economic Views, March, 2010.

19. Swenson, D. L., 1994. The Impact of U.S. Tax Reform on Foreign Direct Investment in the United States, Journal of Public Economics, 54, (2), 243-66.

20. Swenson, D. L., 2004. Foreign Investment and Mediation of Trade Flows, Review of International Economics, 12, (4), 609-29. 


\section{Annexes}

1. Estimation results for independent variable: Life expectancy at birth - Females Dependent Variable: ISD?

Method: Pooled EGLS (Cross-section weights)

Sample (adjusted): 20022008

Included observations: 7 after adjustments

Cross-sections included: 10

Total pool (balanced) observations: 70

Linear estimation after one-step weighting matrix

\begin{tabular}{lrlrr}
\hline \hline \multicolumn{1}{c}{ Variable } & Coefficient & Std. Error & t-Statistic & Prob. \\
\hline \multicolumn{1}{c}{ SVF? } & 26.87660 & 12.69613 & 2.116913 & 0.0379 \\
\hline \hline & -0.280188 & 0.162737 & -1.721730 & 0.0897 \\
\hline \hline R-squared & Weighted Statistics & \\
Adjusted R-squared & -0.171949 & Mean dependent var & 7.394578 \\
S.E. of regression & -0.189184 & S.D. dependent var & 2.892517 \\
F-statistic & 3.154281 & Sum squared resid & 676.5653 \\
Prob(F-statistic) & -9.977018 & Durbin-Watson stat & 0.116525 \\
\hline \hline & 1.000000 & & \\
\hline \hline R-squared & Unweighted Statistics & \\
Sum squared resid & -0.041415 & Mean dependent var & \\
\hline \hline
\end{tabular}

Results generated using EViews 5.1.

2. Estimation results for independent variable: Life expectancy at birth - Males

Dependent Variable: ISD?

Method: Pooled EGLS (Cross-section weights)

Sample (adjusted): 20022008

Included observations: 7 after adjustments

Cross-sections included: 10

Total pool (balanced) observations: 70

Linear estimation after one-step weighting matrix

\begin{tabular}{ccccr}
\hline \hline Variable & Coefficient & Std. Error & t-Statistic & Prob. \\
\hline \hline C & -5.538201 & 7.026693 & -0.788166 & 0.4333 \\
SVB? & 0.157414 & 0.101776 & 1.546678 & 0.1266 \\
\hline
\end{tabular}

Weighted Statistics

\begin{tabular}{llll}
\hline \hline R-squared & 0.298592 & Mean dependent var & 7.961440 \\
Adjusted R-squared & 0.288277 & S.D. dependent var & 3.774663 \\
S.E. of regression & 3.184443 & Sum squared resid & 689.5662 \\
F-statistic & 28.94787 & Durbin-Watson stat & 0.134599 \\
Prob(F-statistic) & 0.000001 & &
\end{tabular}


Unweighted Statistics

\begin{tabular}{lrlr}
\hline \hline R-squared & -0.081599 & Mean dependent var & 6.130952 \\
Sum squared resid & 914.9584 & Durbin-Watson stat & 0.107257 \\
\hline \hline
\end{tabular}

Results generated using EViews 5.1.

\section{Estimation results for independent variable: Fertility rate}

Dependent Variable: ISD?

Method: Pooled EGLS (Cross-section weights)

Sample (adjusted): 20022008

Included observations: 7 after adjustments

Cross-sections included: 10

Total pool (balanced) observations: 70

Linear estimation after one-step weighting matrix

\begin{tabular}{lrrrr}
\hline \multicolumn{1}{c}{ Variable } & Coefficient & Std. Error & t-Statistic & Prob. \\
\hline \multicolumn{1}{c}{ C } & -23.75447 & 4.336877 & -5.477321 & 0.0000 \\
\multicolumn{1}{c}{ RNT? } & 22.47266 & 3.311426 & 6.786401 & 0.0000 \\
\hline \hline Weighted Statistics & \\
R-squared & 0.578122 & Mean dependent var & 8.027617 \\
Adjusted R-squared & 0.571918 & S.D. dependent var & 4.620837 \\
S.E. of regression & 3.023319 & Sum squared resid & 621.5512 \\
F-statistic & 93.18417 & Durbin-Watson stat & 0.177340 \\
Prob(F-statistic) & 0.000000 & & \\
\hline \hline & Unweighted Statistics & \\
\hline \hline R-squared & 0.000461 & Mean dependent var & \\
Sum squared resid & 845.5416 & Durbin-Watson stat & \\
\hline \hline
\end{tabular}

Results generated using EViews 5.1.

4. Estimation results for independent variable: Persons with lower secondary education attainment (as \% of total population aged 15 to 64)

Dependent Variable: ISD?

Method: Pooled EGLS (Cross-section weights)

Sample (adjusted): 20012009

Included observations: 9 after adjustments

Cross-sections included: 10

Total pool (balanced) observations: 90

\begin{tabular}{crrrr}
\hline \hline Variable & Coefficient & Std. Error & t-Statistic & Prob. \\
\hline \hline C & 8.060793 & 0.949770 & 8.487099 & 0.0000 \\
LSE? & -0.108641 & 0.036271 & -2.995240 & 0.0036 \\
\hline \hline
\end{tabular}


Weighted Statistics

\begin{tabular}{lcll}
\hline \hline R-squared & 0.390724 & Mean dependent var & 8.426175 \\
Adjusted R-squared & 0.383800 & S.D. dependent var & 4.069929 \\
S.E. of regression & 3.194829 & Sum squared resid & 898.2100 \\
F-statistic & 56.43367 & Durbin-Watson stat & 0.153056 \\
Prob(F-statistic) & 0.000000 & & \\
\hline \hline & Unweighted Statistics & \multirow{2}{*}{6.114630} \\
R-squared & -0.074947 & Mean dependent var & 0.089283 \\
Sum squared resid & 1238.413 & Durbin-Watson stat & \\
\hline \hline
\end{tabular}

Results generated using EViews 5.1.

\section{Estimation results for independent variable: Persons with upper secondary education attainment (as \% of total population aged 15 to 64)}

Dependent Variable: ISD?

Method: Pooled EGLS (Cross-section weights)

Sample (adjusted): 20012009

Included observations: 9 after adjustments

Cross-sections included: 10

Total pool (balanced) observations: 90

Linear estimation after one-step weighting matrix

\begin{tabular}{lrlll}
\hline \hline \multicolumn{1}{c}{ Variable } & Coefficient & Std. Error & t-Statistic & Prob. \\
\hline \multicolumn{1}{c}{ C } & 2.183406 & 2.398861 & 0.910184 & 0.3652 \\
USE? & 0.048506 & 0.039702 & 1.221744 & 0.2251 \\
\hline \hline \multicolumn{2}{c}{ Weighted Statistics } & \\
\hline \hline R-squared & -0.069727 & Mean dependent var & 7.486172 \\
Adjusted R-squared & -0.081883 & S.D. dependent var & & 2.948121 \\
S.E. of regression & 3.066447 & Sum squared resid & \\
F-statistic & -5.736028 & Durbin-Watson stat & & \\
Prob(F-statistic) & 1.000000 & & \\
\hline \hline & Unweighted Statistics & \\
\hline \hline
\end{tabular}

Results generated using EViews 5.1. 
6. Estimation results for independent variable: Persons with tertiary education attainment (as $\%$ of total population aged 15 to 64)

Dependent Variable: ISD?

Method: Pooled EGLS (Cross-section weights)

Sample (adjusted): 20012009

Included observations: 9 after adjustments

Cross-sections included: 10

Total pool (balanced) observations: 90

Linear estimation after one-step weighting matrix

\begin{tabular}{|c|c|c|c|c|}
\hline Variable & Coefficient & Std. Error & t-Statistic & Prob. \\
\hline $\mathrm{C}$ & 3.910020 & 0.640214 & 6.107366 & 0.0000 \\
\hline PSS? & 0.094938 & 0.045381 & 2.092036 & 0.0393 \\
\hline \multicolumn{5}{|c|}{ Weighted Statistics } \\
\hline R-squared & 0.384362 & Mean dependent var & & 8.422919 \\
\hline Adjusted R-squared & 0.377366 & S.D. dependent var & & 4.209327 \\
\hline S.E. of regression & 3.321459 & Sum squared resid & & 970.8240 \\
\hline F-statistic & 54.94122 & Durbin-Watson stat & & 0.134899 \\
\hline Prob(F-statistic) & 0.000000 & & & \\
\hline \multicolumn{5}{|c|}{ Unweighted Statistics } \\
\hline R-squared & -0.004960 & Mean dependent var & & 6.114630 \\
\hline Sum squared resid & 1157.783 & Durbin-Watson stat & & 0.096380 \\
\hline
\end{tabular}

Results generated using EViews 5.1.

7. Estimation results for independent variable: Foreign languages learned per pupil

Dependent Variable: ISD?

Method: Pooled EGLS (Cross-section weights)

Sample (adjusted): 20012007

Included observations: 7 after adjustments

Cross-sections included: 10

Total pool (balanced) observations: 70

Linear estimation after one-step weighting matrix

\begin{tabular}{|c|c|c|c|c|}
\hline Variable & Coefficient & Std. Error & $\mathrm{t}$-Statistic & Prob. \\
\hline $\mathrm{C}$ & 5.339213 & 0.706706 & 7.555071 & 0.0000 \\
\hline LSI? & -0.259073 & 0.543147 & -0.476985 & 0.6349 \\
\hline \multicolumn{5}{|c|}{ Weighted Statistics } \\
\hline R-squared & 0.379194 & Mean dependent var & & 7.242892 \\
\hline Adjusted R-squared & 0.370064 & S.D. dependent var & & 3.517330 \\
\hline S.E. of regression & 2.791652 & Sum squared resid & & 529.9460 \\
\hline F-statistic & 41.53494 & Durbin-Watson stat & & 0.161336 \\
\hline Prob(F-statistic) & 0.000000 & & & \\
\hline
\end{tabular}


Unweighted Statistics

\begin{tabular}{lrlr}
\hline \hline R-squared & -0.083123 & Mean dependent var & 5.846810 \\
Sum squared resid & 691.9743 & Durbin-Watson stat & 0.150259 \\
\hline \hline
\end{tabular}

Results generated using EViews 5.1.

8. Estimation results for independent variable: Mathematics, science and technology enrolments and graduates (as \% of all graduates)

Dependent Variable: ISD?

Method: Pooled Least Squares

Sample (adjusted): 20002009

Included observations: 10 after adjustments

Cross-sections included: 10

Total pool (unbalanced) observations: 99

\begin{tabular}{|c|c|c|c|c|}
\hline Variable & Coefficient & Std. Error & t-Statistic & Prob. \\
\hline $\mathrm{C}$ & 3.523933 & 1.581461 & 2.228277 & 0.0282 \\
\hline STS? & 0.132560 & 0.079001 & 1.677967 & 0.0966 \\
\hline R-squared & 0.028208 & Mean dependent var & & 6.112626 \\
\hline Adjusted R-squared & 0.018189 & S.D. dependent var & & 3.491897 \\
\hline S.E. of regression & 3.459994 & Akaike info criterion & & 5.340406 \\
\hline Sum squared resid & 1161.241 & Schwarz criterion & & 5.392833 \\
\hline Log likelihood & -262.3501 & F-statistic & & 2.815575 \\
\hline Durbin-Watson stat & 0.128036 & Prob(F-statistic) & & 0.096573 \\
\hline
\end{tabular}

Results generated using EViews 5.1. 